\title{
Seronegative Miller-Fisher syndrome with bulbar palsy - reference to the spectrum of autoimmune neuropathies with the presence of antiganglioside antibodies. A case report
}

\section{Seronegatywny zespół Millera-Fishera z objawami opuszkowymi - odniesienie do spektrum autoimmunologicznych neuropatii z obecnością przeciwciał antygangliozydowych. Opis przypadku}

\author{
Agnieszka Meller $\bowtie$, Monika Gołąb-Janowska, Zofia Osuch, Michał Maj, Przemysław Nowacki
}

Pomorski Uniwersytet Medyczny w Szczecinie, Katedra i Klinika Neurologii, ul. Unii Lubelskiej 1, 71-252 Szczecin

Pomeranian Medical University in Szczecin, Department of Neurology

$\triangle$ agnes_84@o2.pl

\begin{abstract}
Introduction: Miller-Fisher syndrome is rare variant of acute inflammatory demyelinating polyradiculoneuropathy consisting of a clinical triad - ophthalmoplegia, ataxia and areflexia. Case report: We present a case of uncommon clinical manifestations, which were dysarthic speech and dysphagia caused by soft palate paresis. These were preceded by problems with balance, impaired vision and numbness in the upper limbs. Blood
\end{abstract}

serum was negative for anti-GQ1b immunoglobulin G antibodies. The patient received a total of 5 cycles of plasmapheresis. On day 16 of hospitalization the patient showed diminished ataxia symptoms as well as improvement in eyeball mobility and gait. A scheduled check-up 8 weeks after leaving the hospital showed complete recovery from neurological deficit.

Keywords: Miller-Fisher syndrome; polyradiculoneuropathy; autoimmune disease; anti-GQ1b antibodies; dysphagia.

\begin{abstract}
ABSTRAKT
Wstęp: Zespół Millera-Fishera jest rzadkim wariantem ostrej zapalnej poliradikulopatii demielinizacyjnej.

Opis przypadku: Przedstawiono przypadek rzadkiej klinicznej manifestacji zespołu Millera-Fishera pod postacią dyzartrycznej mowy oraz dysfagii spowodowanej porażeniem podniebienia miękkiego. Objawy były poprzedzone problemami z równowagą zaburzeniami widzenia oraz drętwieniem kończyn górnych. W surowicy krwi stwierdzono ujemne przeciwciała anty-GQ1b.
\end{abstract}

W leczeniu zastosowano 5 cykli plazmaferezy. W 16. dniu hospitalizacji odnotowano zmniejszenie ataksji, a także poprawę w zakresie ruchomości gałek ocznych oraz chodu. Po 8 tygodniach od początku wystąpienia objawów choroby uzyskano całkowite ustąpienie deficytu neurologicznego.

Słowa kluczowe: zespół Millera-Fishera; poliradikuloneuropatia; choroby autoimmunologiczne; przeciwciała anty-GQ1b; dysfagia.

\section{INTRODUCTION}

The concept of Guillain-Barré syndrome (GBS) has changed over the years. In the past, it used to be defined as a single condition, while now it is referred to as a group of acute neuropathies of a one-phase course induced by autoimmune factors.

The condition is most likely caused by molecular mimicry between antibodies reacting with antigens of infectious agents such as viruses and bacteria cross-reacting with epitopes present in the peripheral nervous system. This, in turn, results in damage to myelin and/or nerve axons [1]. Clinically, the most common, 'classic', form of GBS accounting for $60-90 \%$ of all GBS cases is acute inflammatory demyelinating polyradiculoneuropathy. Other, much less common forms, include acute motor sensory axonal neuropathy $-5-10 \%$ and Miller-Fisher syndrome (MFS) $-3-5 \%$ of GBS cases [2].
Miller-Fisher syndrome was first described as a GBS variant by Fisher in 1956 [3]. There are three characteristic signs of the condition: ophthalmoplegia, ataxia and areflexia, first recognised by Collier in 1932 [4]. Ataxia mainly affects gait and the torso rather than the limbs. The initial symptoms include diplopia, which occurs in about $40 \%$ of afflicted patients, and balance disorders - around 20\% [5].

The disease process may cause damage to cranial nerves IX, X and XII. Tetraplegia constitutes an element of MFS or it may be a sign of the classic Guillain-Barré syndrome overlapping MFS (a nerve conductive study provides a conclusive diagnosis in this respect) [6]. Miller-Fisher syndrome which usually occurs between the ages of 35 and 60, is more prevalent in men. In about $60 \%$ of all cases it is preceded by the infection of the airways or digestive tract [7]. Antiganglioside antibodies are present in the blood of most patients. Although typical MFS is associated with the presence of anti-GQ1b 
antibodies, a small percentage of patients (about $5 \%$ ) are GQ1b-seronegative [8].

Increased levels of cerebrospinal fluid (CSF) proteins appear in $60-70 \%$ of patients within the first week of disease onset [9]. Treatment is the same as for GBS. The symptoms subside within 1-9 months [10].

In this article we describe the case of a patient with a very rare seronegative form of Miller-Fisher syndrome accompanied by bulbar symptoms resulting from soft palate paresis, which is also uncommon in this condition. In the discussion we compare the case together with other acute neuropathies which constitute a form of a continuum of diseases connected with the expression of antiganglioside antibodies in the nervous system.

\section{CASE REPORT}

A 60-year-old woman was referred to a neurological outpatient clinic after she had complained of severe, persistent dizziness, which she had suffered from since early morning of the previous day, as well as gait and balance problems. These were followed by impaired vision ('blurred vision'), numbness in the upper limbs and slower speech, which she complained of on the day of admission to the hospital.

The complaints were believed to have been caused by significantly elevated blood pressure (200/100 mmHg). Having been administered antihypertensives, the patient was discharged with some hypertension treatment recommendations. An outpatient laryngological examination ruled out a peripheral character of the ailments. Two weeks later the woman reported to the hospital again.

The history revealed hypothyroidism caused by Hashimoto's thyroiditis, hypertension, type 2 diabetes, and anxiety and depression disorder. She also reported developing bronchitis about 6 weeks prior to the onset of the symptoms.

The neurological examination performed on admission revealed bilateral proptosis, narrowing of the palpebral fissures, but no abnormal eye movement, diplopia or any other abnormalities. The day after her admission brought an exacerbation of dysarthria and the onset of dysphagia, soft palate paralysis and impaired upward gaze. The next day the patient developed ophthalmoplegia, non-reactive pupils and symmetrical hyporeflexia. No paresis of the limbs was present, and the woman did not report any abnormalities in exteroceptive and proprioceptive sensation. On day 4 she presented with appendicular ataxia and a positive Romberg's test.

Lab tests revealed no abnormalities except those in the CSF. Electroencephalographic reading was within normal limits. Computed tomography scan of the head showed no changes. A complementary magnetic resonance imaging scan disclosed an 'old' micro-stroke lesion of $6 \mathrm{~mm}$ in diameter in the right corona radiata. Analysis of the cerebrospinal fluid revealed a slightly elevated concentration of protein $-56.8 \mathrm{mg} / \mathrm{dL}$ (lab norm $<45 \mathrm{mg} / \mathrm{dL}$ ). The sediment of the CSF, except for a few activated lymphocytes, was normal. Differential diagnosis was performed to establish any transmission deficit in nerve impulses to muscles. However, repetitive nerve stimulation of the units: the right facial nerve - the orbicularis oculi muscle and the right accessory nerve - the trapezius muscle ruled out any pathology.

Electromyography excluded myogenic and neurogenic deterioration within the examined muscles. Sensory and motor nerve conduction parameters were normal. No immunoglobulin M or immunoglobulin G (IgG) antibodies reacting with recombined antigens GM1, GD1b, GQ1b were detected in the collected serum samples.

Having analysed the clinical picture of the signs and symptoms, we diagnosed the patient with Miller-Fisher syndrome and started treatment. She was given a total of 5 cycles of plasmapheresis, with the first one administered on the $6^{\text {th }}$ day of hospitalization. Additionally, motor rehabilitation was introduced. On the $16^{\text {th }}$ day in hospital the patient showed diminished ataxia symptoms as well as improvement in eyeball mobility and gait. She was transferred to the department of motor rehabilitation for further treatment.

\section{DISCUSSION}

Our patient presented with the MFS classic symptom triad of ophthalmoplegia, ataxia and areflexia. Concomitant symptoms included numbness in both hands, typical of this syndrome (reported by $40 \%$ of MFS patients) [4], accompanied by the absence of limb paresis or any abnormalities in an electronystagmography test. Clinically significant and relatively uncommon MFS symptoms we observed in our patient were dysarthric speech and dysphagia caused by soft palate paresis.

The presenting symptoms did not indicate Bickersaff's brain stem encephalitis (BBE), which is considered a subtype of MFS [11]. Both disorders are heralded by infection and the possible presence of anti-GQ1b antibodies. Patients also develop ophthalmoplegia and ataxia [11]. Unlike MFS, BBE is characterised by quantitative disorders of consciousness such as pathological drowsiness, pyramidal and sensory signs [12]. Myasthenia was ruled out since no typical symptoms were observed and, with the presence of ophthalmoplegia and ataxia, the nerve stimulation test yielded negative results. In 1986, Ropper [13] described the pharyngeal-cervical-brachial (PCB) variant of GBS, which is characterised by dysphagia, and weakness of muscles of the neck, arm and shoulder girdle in the dominant limb. Koga et al. [14] proved that $20 \%$ of MFS patients can present with paresis of the nasopharynx muscles accompanied by paresis of the muscles of the neck and arm in the dominant upper extremity. It can therefore be assumed that MFS/GBS, BBE/GBS, and PCB/GBS constitute the continuum (spectrum) of the symptoms [15]. In the described case only the soft palate was affected with paresis.

Miller-Fisher syndrome diagnosis is established on the basis of typical neurological signs and complemented by albuminocytologic dissociation in the CSF and presence of anti-GQ1b antibodies in the blood serum [8]. 
Immunohistochemical tests carried out in MFS patients show an elevated concentration of GQ1b in the subependymal brainstem region encompassing the cerebral aqueduct and the fourth ventricle. The area is the site of centres responsible for vertical and horizontal eye movements. GQ1b antibodies were proved to be directed against nervous tissue of this area, which consequently explains the occurrence of external ophthalmoplegia $[16,17]$. The fact that anti-GQ1b antibodies show a tendency for cross-reactivity with GT1a gangliosides, characteristic for PCB patients (here bulbar palsy is the main symptom), may lead to the assumption of the hypothesis that the cross-reactivity can be blamed for the damage to cranial nerves IX and X, observed in MFS patients $[18,19]$. It is believed that the presence of the antibodies established through staining of the molecular layer of the cerebellar cortex is connected with the manifestation of ataxia symptoms [20].

In seropositive MFS the highest concentrations of anti-GQ1b antibodies are found in its initial phase. They normally disappear within the next 3-4 weeks, which is the result of clinical recovery. Approximately $5 \%$ of patients are seronegative [21]. The presence of other antibodies contributory to the pathogenesis of the condition has been reported. Koga et al. [14] proved the presence of IgG - antibodies to GM1b, Gd1c, Ga1NAc-GM1b and ganglioside complexes as a serological marker for GQ1bseronegative patients. The pathogenesis of these antibodies requires further investigation [18].

The clinical course of both seropositive and seronegative MFS is similar [21].

We did not find in our patient antibodies to antigens GM1,GD1b, GQ1b.

The described case is believed to be an instance of MFS affecting cranial nerves, which results in the paralysis of the soft palate.

A scheduled check-up 8 weeks after leaving the hospital showed the patient's complete recovery from neurological deficit. She still remains asymptomatic.

\section{REFERENCES}

1. Levin MC, Krichavsky M, Berk J, Foley S, Rosenfeld M, Dalmau J, et al. Neuronal molecular mimicry in immune-mediated meurologic disease. Ann Neurol 1998;44(1):87-98. doi: 10.1002/ana.410440115.

2. Ropper AH. The Guillain-Barré syndrome. N Engl J Med 1992;326(17):11306. doi: 10.1056/NEJM199204233261706.
3. Fisher M. An unusual variant of acute idiopathic polyneuritis (syndrome of ophthalmoplegia, ataxia, and areflexia). N Engl J Med 1956;255(2):5765. doi: 10.1056/NEJM195607122550201.

4. Collier J. Peripheral neuritis. Edinburgh Med J 1932;39:601-18.

5. Bilińska M, Koszewicz M. Zespół Millera Fishera z dominującymi zaburzeniami połykania i mowy. Adv Clin Exp Med 2004;13(3):515-19.

6. Katsuno M, Ando T, Hakusui S, Yanagi T, Sobue G. Motor conduction studies in Miller Fisher syndrome with severe tetraparesis. Muscle Nerve 2002;25(2):378-82.

7. Berlit P, Rakicky J. The Miller Fisher syndrome. Review of the literature. J Clin Neuroophthalmol 1992;12(1):57-63.

8. Chiba A, Kusunoki S, Obata H, Machinami R, Kanazawa I. Serum anti-GQ1b immunoglobulin $\mathrm{G}$ antibody is associated with ophthalmoplegia in Miller Fisher syndrome and Guillain-Barré syndrome: clinical and immunohistochemical studies. Neurology 1993;43(10):1911-7.

9. Ito M, Kubawara S, Odaka M, Misawa S, Koga M, Hirata K, et al. Bickerstaff's brainstem encephalitis and Fisher syndrome form a continuous spectrum: clinical analysis of 581 cases. J Neurol 2008;255(5):674-82. doi: 10.1007/s00415-008-0775-0.

10. Mazur-Melewska K, Szwed K, Figlerowicz M, Figlerowicz M, Służewski W, Bareńska I, et al. Heterogenność zespołu Guillaina-Barrego na przykładzie przypadków. Pediatr Pol 2012;87(1):102-5.

11. Yuki N, Sato S, Tsuji S, Hozumi I, Miyatake T. An immunologic abnormality common to Bickerstaff's brain stem encephalitis and Fisher's syndrome. J Neurol Sci 1993;118(1):83-87.

12. Odaka M, Yuki N, Yamada, M, Koga M, Takemi T, Hirata K, et al. Bickerstaff's brainstem encephalitis: clinical features of 62 cases and a subgroup associated with Guillain-Barré syndrome. Brain 2003;126(10):2279-90. doi: 10.1093/brain/awg233.

13. Ropper AH. Unusual clinical variants and signs in Guillain-Barré syndrome. Arch Neurol 1986;43(11):1150-2. doi: 10.1001/archneur. 1986.00520110044012.

14. Koga M, Gilbert M, Takahashi M, Li J, Hirata K, Kanda T, et al. GQ1b-seronegative Fisher syndrome: clinical features and new serological markers. J Neurol 2012;259(7):1366-74. doi: 10.1007/s00415-011-6360-y.

15. Hughes RA, Cornblath DR. Guillain-Barré syndrome. Lancet 2005; 366(9497):1653-66. doi: 10.1016/S0140-6736(05)67665-9.

16. Jacobs BC, Hazenberg MP, van Doorn PA, Endtz HP, van der Meche FG. Cross-reactive antibodies against gangliosides and Campylobacter jejuni lipopolysaccharides in patients with Guillain-Barré or Miller Fisher syndrome. J Infect Dis 1997;175(3):729-33.

17. Chiba A, Kusunoki S, Obata H, Machinami R, Kanazawa I. Ganglioside composition of the human cranial nerves, with special reference to pathophysiology of Miller Fisher syndrome. Brain Res 1997;745(1-2):32-6.

18. Chiba A, Kusunoki S, Shimizu T, Kanazawa I. Serum IgG antibody to ganglioside GQ1b is a possible marker of Miller Fisher syndrome. Ann Neurol 1992;31(6): 677-9. doi: 10.1002/ana.410310619.

19. Nagashima T, Koga M, Odaka M, Hirata K, Yuki N. Continuous spectrum of pharyngeal-cervical-brachial variant of Guillain-Barré syndrome. Arch Neurol 2007;64(10):1519-23. doi: 10.1001/archneur.64.10.1519.

20. Noureldine MH, Sweid A, Ahdab R. Miller Fisher syndrome presenting as palate paralysis. J Neuroimmunol 2016;15(298):130-1. doi: 10.1016/j. jneuroim.2016.07.013.

21. Kornberg AJ, Pestronk A, Blume GM, Lopate G, Yue J, Hahn A. Selective staining of the cerebellar molecular layer by serum IgG in Miller-Fisher syndromes. Neurology 1996;47(5):1317-20. 